第75回日本内科学会講演会（1978年）

\title{
シンポジウム 浮腫
}

\section{（1）発生機序 i ）全身性因子}

\author{
東京大学医学部第一内科 \\ 長坂 昌人 \\ 帝京大学医学部第一内科 \\ 木野内 喬
}

\section{SYMPOSIUM ON EDEMA (1) PATHOGENESIS. i) SYSTEMIC FACTORS NA REGULATORY SYSTEM AND EDEMA}

Masahito NAGaSAKa, MD

The First Department of Medicine, Faculty of Medicine, University of Tokyo, Tokyo

Takashi Kinouchi, MD

The First Department of Internal Medicine, Faculty of Medicine, Teikyo University, Tokyo

浮腫論の基本問題は，（1）何故浮腫になつた かと，（2）何故その箇所にあるかの 2 点であろ 5.前者がいわゆる全身性因子であり，後者が局 所性因子である．患者の浮腫に対し食塩制限の有 効なことから，浮腫の成因として特にNaの眝留 が重要であると認められるに到つた。すなわち浮 腫とはNa代謝の異常であると考えられた，以下 に第二次大戦後に行なわれた主なNa調節学説を 紹介し論評する1)。いずれる一部の事実を説明し 得たが，全般的な説明には成功していない。

まず糸球体沪過值GFRの低下がNa排灌を減少 するというSmith学派の説は，第一に患者の利尿 が必ずしす腎血行動態の改善と平行しないこと， 次にそれらの值が亟めて低い腎疾患に際しても， 常に浮腫があるとは限らないこと，そしてNa調 節のためのみに例えばGFRが変動するとは考学難 い等の難点があつた。

次にレニン・アンジオテンシン・アルドステロ ン系の亢進が夥留を起こすという学説に対し ては，第一に浮腫患者でアルドステロンが必ずし あ高くないこと，次にアルドステロンを連日投与
しても，いわゆるニスケープ現象により $\mathrm{Na}$ 停滞 に限度のあること等から，それのみで調節可能と は考え難いとされた，ただ調節機能の遂行に対 しパーミッシヴ働きのあることは認められてい る。

上の二つの学説の後をらけて現れた第 3 因子説 は，体液因子と物理因子の双方が考えられてい る.前者は今迄に見出された限りにおいて，作用 の発現時間等に未だ難点があるとされる．後者は 尿細管周辺の毛細血管に括けるStarling諸力を取 り上げるのであるが，肝腎の作用点と目される遠 位尿細管では, 直達効果が小さいのが問題点であ る。

その他Bargerの腎内血流再分布説は，患者での 測定が必ずしも可能でなく，又動物実験において わ賛否相半ばしている，腎神経の影響については 未だデータ不足である。

このような中にあつてGuytonは大規模なコンピ ニータ・シミュレーションにより，体液量調節采 を全体として眺める可能性を開いた。しかし彼の 模型では体液の調節が余りにも循環系の調節に強 
Process dynamics

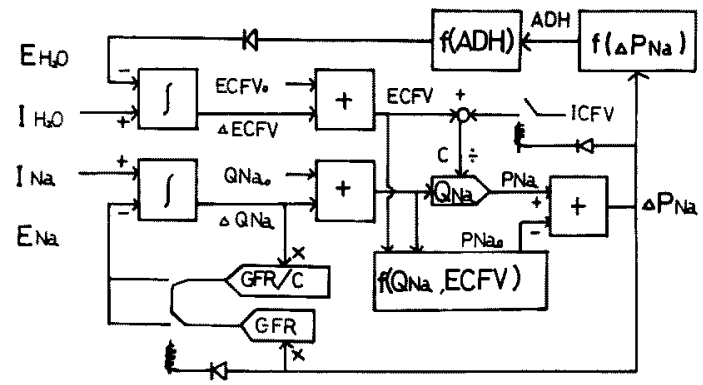

因1、Na 処理系のブロック図

表 1.眓1および表 2 の略号表 Abbreviations( 1)

$E_{H_{2}} \mathrm{O}$ Water excretion rate

${ }_{i} \mathrm{H}_{2} \mathrm{O}$ Water intake rate

ENa $\mathrm{Na}$ excretion rate

I Na Na intake rate

ECFV Extracellular fluid volume

ICFV Intracellular fluid volume

C Osmotic volume

$Q_{\mathrm{Na}}$ Total $\mathrm{Na}$ content

$P_{\mathrm{Na}}$ Plasma $\mathrm{Na}$ concentration

GFR Glomerular filtration rate

ADH Antidiuretic hormone

Suffix. Initial value

$\Delta \quad$ Changes in its value

く結び付けられていたために，Na独自の調節を 観察するには不便があつた。そこでわれわれは今 回必要な範囲のシミュレーションを試みたので， それを提示する（図1，表1）.ちなみにシミ二 レーションの技法は，初めそれによつて未知の法 則が見出されるかの期待があつたが，現在ではむ しろそれぞれの模型の可能性と㷌結を論じるため の道具となつたの感がある。

われわれの模型の基礎となつた実験について以 下簡単に述べる。まずイヌに高張食塩水を負荷す ると，尿中の毎分 $\mathrm{Na}$ 排泄量は血浆 $\mathrm{Na}$ 濃度 の上昇 に比例し，その相関係数は0.54である ${ }^{23)}$. 次に Na排泄量とGFRとの相関を見ると0.72であつた。 そこで血浆Na濃度の上昇分とGFRの積，すなわち 系球体沪夜中のNa負荷の増大分を算出し，それと
尿中Na排泄量との相関を求めると0.85と改善し t.

高張食塩水負荷の 4 時間前に大量の生理食塩水 を与えて置くと，尿中Na排泄が急激に增大し始 める間值に相当する血㜣Na濃度が低下する"。 の低下は高張食塩水負荷の 2 時間前に, 大量の丁 ルドステロンを筋注しても防げなかつた。なおて ルドステロン前処置の有無にかかからず，新しい 闒值に 相当する值からの 血浆 $\mathrm{Na}$ 濃度上昇分を用 いて，先と同様の系球体汇液中の $\mathrm{Na}$ 負荷増大を 計算し，尿中Na排泄量との相関を求めるとその 公配は殆亡゙一致し，閵值の低下以外の $\mathrm{Na}$ 処理機 構は全く変化しないことが明らかになつた。

次に大量の生理食塩水で容量負荷を行ならと， 血浆Na濃度は変化しないが 尿中Na排泄 は矢張增 大する5．対照として同量のブドウ楉腋を負荷し た場合は，血将Na濃度 は低下したが尿中Na排泄 は増さなかつた。な拈生理食塩水負荷が終ると尿 中Na排泄は直に減少し始めるが，引続きブドウ 糖液で容量負荷を持続してもNa排泄の減少は抑 えられなかつた。

ここでバランス計算を行ない体内に残存してい るNa負荷量と，尿中Na排泄量との関係を見ると 再び直線関係が見出された。この直線の勾配から 時定数を算出すると，驚くことに先の高張食塩水 負荷時に得られた時定数と殆ど同じ大きさであつ た。その值はさらにヒトに食塩を経口負荷した時 の時定数とも大きな差はない，すなわち生体のNa 負荷に対する反応は，条件の差を超えてかなり一 様であることが椝われた。

生理食塩水の代りに等張重曹水による容量負荷 を試みたが，Na排泄の経過は殆ど同型でCl負荷 の有無はNa処理系に影響がない。

ブドウ糖による容量負荷の際は血将中のNaお よびCl濃度が低下するが，それに引続いて高張食 塩水を負荷すると矢張或る血浆 $\mathrm{Na}$ 濃度を境に尿 中Na排泄が急激に増大寸る。この闇值に相当す る濃度は対照より低い，すなわち先の生理食塩水 前負荷の実験と同じく，容量負荷は食塩を伴わな 
くても血樍Naの閾值濃度を低下させることが明 らかとなつた，又この際高張重曹水を用いてる Na排泄の経過は，高張食塩水の場合と全く同型 であつた。ここでむNa処理系はClの同伴有無に かかわらず働くことが示された。

生理食塩水の負荷開始時に利尿薬（フロセマイ ド）を静注して見た。すると最初の90分間は単な る容量負荷に比して尿中Na排泄は増大したが， 4 時間迄観察すると対照との差はかなり小さくな り，代償機転の存在することが認められた．この 成績はNa調節系はNa排泄の行き過ぎに対して， 鋭敏に反応し得ることを意味しょう。

以上述べて来たことをシミュレーションに必要 なので表式化したるのを表 2 に示す。ここで多少 補足すべき点があるので以下に記す。先ず容量負 荷若しくはNa負荷が闇値に相当する血浆 $\mathrm{Na}$ 濃度 を変兄る機構であるが，これは今迄容量受容器或 いは第 3 因子等と呼ばれたものに相当する．この 部分の定量化は未だ行なわれていない。

次に体内Na保有量の基準值とアルドステロン の関係である。この関係については古くSwingle らの副腎摘出動物を，グルニコルチコイドのみで 維持すると体内の $\mathrm{Na}$ 保有量が低下するという成 樍がある，又原発性アルドステロン症の際体内の Na保有量は増大寸るといわれている.さらにDavis らの実験心不全イヌに拉いて, 副腎摘出時のNa 眝留レベルがDOCAの維持量に比例したという成 績がある。そのような点を併せて体内Na保有量

表 2。図1のための関係式

System dynamic relations (1)

$I_{k a}=C \frac{d P_{\text {Na }}}{d t} \cdot G r R \cdot \Delta P_{N a}$

$\Delta P_{\text {Na }}=P_{\text {Na }}-P_{\text {Nad }}\left(P_{\text {Na }}-P_{N a a_{1}}>0\right)$

$$
=0 \quad\left(P_{N a}-P_{N a, 0} \leqslant 0\right)
$$

$Q_{\mathrm{Nu}}=\mathrm{ECFV} \cdot \mathrm{P}_{\mathrm{N}}$

$Q_{\text {Nat }}=f($ Ald $)$

$$
\begin{aligned}
& \left.E_{N a}=G F R \cdot \triangle P_{\text {NR }} \quad \text { (ECFV }=\text { const. }\right) \\
& =\frac{G F R}{C} \cdot \Delta Q_{\text {N }} \quad \text { (ECFV } \neq \text { const. ) } \\
& P_{\text {Nan }}=f\left(Q_{\text {Na }}, E C F V\right)
\end{aligned}
$$

のレベルとアルドステロンの間に相関があると推 定した。

ところで最近 のYoung ら ( $^{6}$ Watkinsら ${ }^{7)}$ の研究 は, Na保有量のレベルが変動する時, すなわち 食塩制限，負荷或いは実験心不全に際して，フル ドステロンが大きく変動して新しいバランスへの 到達が促進される，制御理論でいら微分作用が認 められることを示して注目される。

長期の食塩負荷については吉村の古い成績があ るが，一見して明らかな如く一次おくれの形であ り，ここでむNa排泄の増大が体内Na保有量の増 大に比例していることがわかる(図 2) $)^{8)}$ 。この

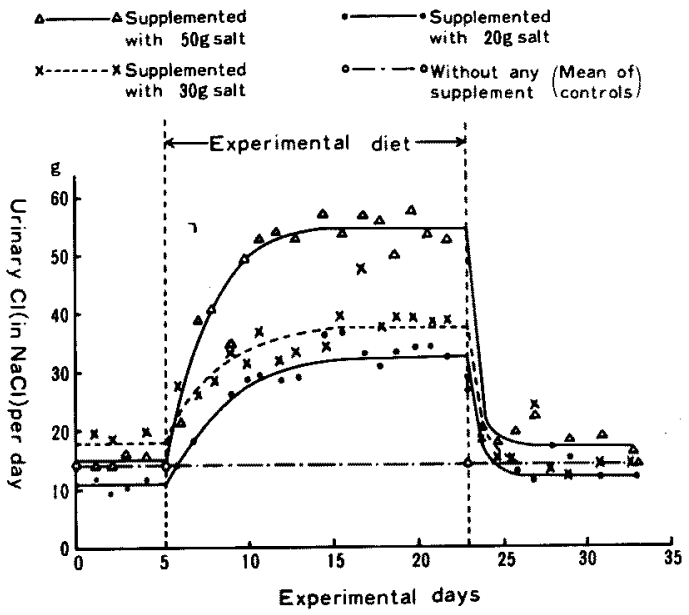

因2，上トに打ける食塩鱼荷の処理（吉村他， 1952)

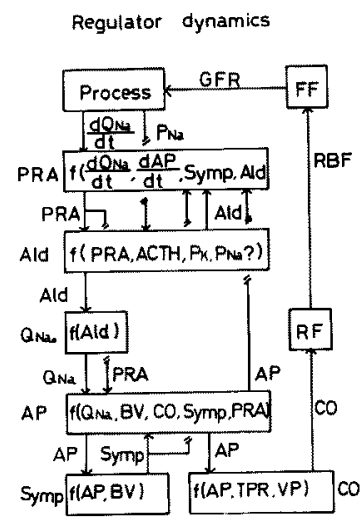

図 3， $\mathrm{Na}$ 調節系の概略図 
際アルドステロン分泌は過渡的に減少するである うが，そのことは尿中Na排㴹を增大させ負荷の 影紋乘らげるに役立ち，微分作用の一つの效果 と䍐われる.な掟常状態に近ずけばアルドステ ロンは再びもとのレベルか，或いはそれよりる少 し高いレベルに落着くと推定される。

以上でNa処理系の解説を終わるが，この系は生 体の中ではさらに主として腎外の調節系と組合わ されていると考えられる。そのような広義のNa 調節系を現段階に知られていることからまとめて

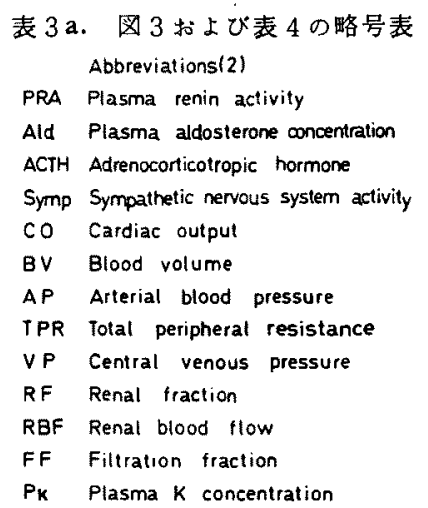

表 3 b. 図 3 お゙よ゙表 4 の略号表 Abbreviations (3)

$\mathrm{MO}_{2} \mathrm{O}_{2}$ consumption rate

TP Total plasma protein concentration

QP Total plasma protein content

PV Plasma volume

QRBC Total red blood cell content

Ht Hematocrit

表 4 図 3 のための奧係式（一部）

System dynamic relations (2)

$G F R=f(R B F)=f(C O)$

$C O=f(A P, T P R, V P)=f\left(M O_{2}\right)$

Ald $=\left\{\left(P R A, A C T H, P_{K}, P_{\text {NLZ }} ?\right)\right.$

$P R A=f\left(\frac{d Q_{N a}}{d t}\right.$, Symp, $\frac{d A P}{d t}$, Ald $)$

$P V=f(E C F V)$

$Q P=T P \cdot P V$

$Q R B C=\mathrm{Ht} \cdot \mathrm{BV}$

$B V=P V+Q R B C$

$A P=f\left(Q_{\mathrm{Na}}, B V, C O\right.$. Symp, $\left.P R A\right)$

Symp $=f(A P, B V)$
表示寸る(図 3，表 3)．この分野の定量化は殆ど 手が付けられていないが，一部の関俰式を示せば 表 4 の如きのであろう.今後の研究が望まれる.

\section{結 論}

生体にはNaに特異的な調節系があり，それには 体内のNa保有量を一定に保つという面と，負荷又 は制限に対しバランスをとるという面とがある。 前者に対しては例えば偱環系からの要求その他の 影響が考えられ，アルドステロンの或るレベルが 必要なようである。後者に対しては体内 $\mathrm{Na}$ 量の変 動が一次的に関係し，アルドステロンはもし関係 するとすれば，適応を促進する如く逆方向に変動 するもののよらである．ただし浮腫の原因が存在 しNa保有量のレベルが高められる時期には，一 過性にアルドステロン分泌が増大するであろう。

$\mathrm{Na}$ 処理系の立場から見れば，浮腫とは結局何 らかの原因により体内 $\mathrm{Na}$ 保有量のレベルが增大 せしめられ， $\mathrm{Na}$ 調節系の中で新しいレベルにリ セットされた状態ということになる。Na眝留が 高血圧でなく他なら浮腫になるといら点は，生 体のバランスのみでなく体内の分布異常の問題が 加わつているといわねばならないであろう。

\section{文献}

1) 長坂昌人：体液分布調節の巽常, 内科七 ナ一，CV 2．5つ血性心不全，永井甾忘，大阪 (即刷中).

2) Nagasaka $M$, et al: Constant infusion of hypertonic saline in the dog. I. Kinetic analysis. Jap Heart J 9: 281, 1968.

3) ibid: ibid. V. The relative importance of plasma Na concentration and GFR as the determinants of renal $\mathrm{Na}$ excretion. Jap Heart J 11: 541, 1970.

4) ibid: ibid. III. Effects of physiologic saline preloading and of aldosterone thereon. Jap Heart J 10: 428, 1969.

5) ibid: Sodium excretion in volume-expanded dogs. I. Comparison of physiological saline and $5 \%$ glucose solution. Jap Heart $\mathrm{J} 19$ : 94, 1978.

6) Young DB and Guyton AC: Steady state aldosterone dose-response relationships. Circ Res 40: 138, 1977.

7) Watkins $L$, et al: The renin-angiotensinaldosterone system in congestive failure in conscious dogs. J Clin Invest 57: 1606, 1976.

8) Yoshimura $\mathrm{H}$, et al: Studies on the reactivity of skin vessels to extreme cold, part III. Effects of diets on the reactivity of skin vessels to cold. Jap J Physiol 2: 310, 1952. 